\title{
鉄系焼結材の軽 切削*
}

\author{
Tadaaki Sugita and Miyoshi Tanaka: Light Machining of Sintered Iron \\ Compact. \\ The machining performances of three types of cutting tools in light machining of the sintered iron \\ compacts, which are sintered alumina containing titanium carbide, cemented carbide and cermet, have \\ been discussed in this short note. Also, the performance of each tool was evaluated in the continuous \\ cutting condition by turning and in the intermittent cutting condition by face milling. Consequently, \\ the experimental results have indicated that the sintered alumina containing titanium carbide was \\ superior to the other tools from the viewpoint of tool life.
}

(Received Nobember 20, 1975)

\section{I 緒言}

かなり高精度に成形，㹸成されるので，徒来から機械 加工を必要としないとされることが多かった粉末治金製 品屯, 時代之と屯に，珍状の複雑化拈よび材質の高品質 化にと屯なって，より高精度を要求されるようになり， 切削加工と加研削加工の必要性加高まってきた，6っと 屯, 古くから成形不能個所の機械扣工という問題は不可 避であったの事実であるが．ところが焼結材の機械加 工について研究されたことはまことに少なくわずかに2， 3 の断片的な報告にとどまる1 心の薄い中で，大森らは，烤結材の切削の必要性を早く から見通し，を机関して系統的な研究を行なっている。 これはこの種の基礎的な研究として唯一のあの之高く評 洒される の進歩が著しく，古い研究成果がそのまま実用的な情報 として利用し得ないことである.たとえば，乙れまでサ 一メット工具で切削した報告はなく，わずかに $1 ， 2$ 亿 すぎない9,10). また，七ラミック工具については、コー ルドプレスチップに関しての報告8)が一つあって，よく ない結果が報告されている。しかし，て机西近年，製法 がホットプレスにかわって飛躍的に性能向上をみせ，そ の上，最近になってカーバイド系セラミック工其の安定 なものが出るにおよんで，かってのセラミック工具の様 相は一変している。したがって，てのような現状から再 び，断片的であっても，最近の工具性能についての情報 が是非必要となってくる.

そとで，本報告ではセラミック，サーメット，超硬合 金の各工具の切削性能飞ついて二，三の結果を述べる.
㘹結材を切削することは，他の材料の切削とは異なり， 常に高精度加工をしなければならないという目的から， 当然，仕上面あらさが問題となるが，それを良い状態に あっていくためには，何よりあまず，工具が耐摩耗性に すぐれていなければならないすすなわち，長時間の工具 寿命を保証できる向のでなければならない，その観点で， ここでは，まず，工貝寿命の問題だけを取り扱うことに する.また，切削形態としては，烧結材のように一般に 複雑形状をとることの多い場合には，連続切削と変わら ないぐらいの比率で断続切削が必要となるので, 両切削 形態についての工具性能を比較してみる.

\section{【実 験 方 法}

連続切削として旋削丸削りを乾式で行なった．この上 きに用いた試験旋盤は西部電機の 10,000 r.p.m のもので ある. 工具材質は，超硬合金 P 10 サーメット，七ラ ミック(カーバイド系) で, 工具形犾は $-5^{\circ},-6^{\circ}, 5^{\circ}$, $6^{\circ}, 15^{\circ}, 0^{\circ}, 0.8 \mathrm{R}$ であるが，一部すくい角を変えてその 影響をも検討した. 切削条件は，仕上軽切削として，送 り $0.1 \mathrm{~mm} / \mathrm{rev}$. 切込みを $0.3 \mathrm{~mm}$ とし切削速度は 100 $400 \mathrm{~m} / \mathrm{min}$ とした.

断続切削は正面フライス削りを乾式で行なった，使用 機械は，日立精機 No.3 㹂フライスである. 使用カッタ は住友マイススタンダードタイプ8インチであって，1 本刃とした. 工具形状はラジアルレーキー $5^{\circ}$,アキシャ ルレーキ -6 $6^{\circ}$ でエンゲージアングルは $15^{\circ} \sim 24^{\circ}$ である.

* 昭和50年11月20日受理

** 金沢大学工学部 7920 金沢市小立野2丁目40-20

*** 日本タングステン(株) テ815 福岡市南区塩原字山王 


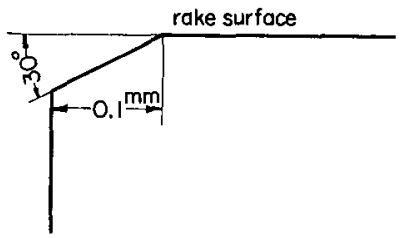

Fig. 1. Shape of cutting edge.

工具寿命は連続切削，断続切削上むに $\mathrm{V}_{\mathrm{B}}=0.4 \mathrm{~mm} の$ 上 きとした：また，チップの切对部には，Fig.1 亿示すよ うに $0.1 \mathrm{~mm}$ 稫のランドをすくい面に $30^{\circ}$ 傾けている. 被削材は Fe-C-1\% Cu 系の焼結材で， $100 \phi$ 直径 $\times 10$ 軍 さのあのを多数枚重ねてクランプし，棒状に構成して切 削に供した。

\section{III 実験結果亡検討}

\section{III - 1 連続切削の工具寿命}

はじめに工具の切削性能にとって影響の大きい工具形 状のうちすくい角の影響について検討してみる．Fig. 2 はカーバイド采セラミック工具のすくい角をかえて，そ れと工具寿命との関係を求めたものである. 図に示すよ うに，正のすくい角加負のすくい角に変化するにつれ て工具寿命は長くなる。一般的には，切机味の問題とか 切削熱の問題加ら正のすくい角の方が士具の形状として は有利なととが多いが，この場合にはその逆の結果を示 している. セラミック工具のように高温での化学的安定 性にすぐれ，高湿強さ，硬さが低下しにくく11)，し加す 耐摩耗性に富む ${ }^{11)}$ 埸合には，切刃の切削熱による軟化，

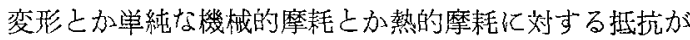
大きい，乙れに対して，甘゙い性であるために切刃の微視 的破壊（ミクロチッピング）が発生しやすく12)，それが 工具摩耗を間接的に促進することが考えられる. このよ うな場合には，切刃を補強する必要があり，真のすくい 角をとったり，切刃棱をチャンファしてランドを設ける
と著しい効果がある、Fig. 2 はそのような場合に相当す 万.

このような考え方で，乙机までセラミック工具には切 刃にランドがつけられてきたが，そのランド幅をどれだ けによるかが間題である，少なくとも，送り最をこえる ような大きなランドは必要がないばかりではなくむし ろ精密加工の立場からみて有害である.たとえば，ここ で採用した工具形状のように，すくい面に対して $-30^{\circ}$ の角度を屯ったランドをつけ，-50のすくい角をとっ たとし，切削がランド幅内でのみ行なわれたとすると， ー350のすくい角をとったととになって，工具自体にと ったすくい角の意味がなくなる. その結果，苾い切れ味 の工具で削ることになって仕上面あらさは劣下する13). したがって，ランド幅は，切刃を補強する役割を果たす 最小限の寸法でなりればならない12．街揧を伴う节酷 な断続切削の場合にでも, ランド幅は送り量の0.8〜0.85 位で十分であっだ4)ととからみて，連続切削では0.6〜 0.8 位でよいと思われる.すくい面での切くず接触幅が 送り量の1.5〜 2 倍12)であるので，ての場合には切刃の 補強亡切れ味の回復をむたらす2段すくい角の状態にな り好ましい結果となるであるう。

Fig. 3 は連続切削の V-T 線図を示す. 比較のために 川崎製鉄で行なわ机たもの9) 6示す。これによると，超 硬材種としては，K種よりも $\mathrm{P}$ 種が適当である。またサ ーメットは意外にも高い切削性能を示さない，ただし， この場合に材質的にみて，適些なサーメットが使用され たかどうかの点に若干の問題もあり，ての結果だけでサ ーメットを不適当と判断することはできない，たとえば， 川鉄での奏験結果上筆者のそれの間に約10倍屯の工具夷 命のちがいがあることに注目しなければならない。

いずれにしても，カーバイド系セラミックのもっとも 安定してしかも高い切削性能を佮している.すなわち， 従来のセラミックのように低速域に拉いてチッピングを

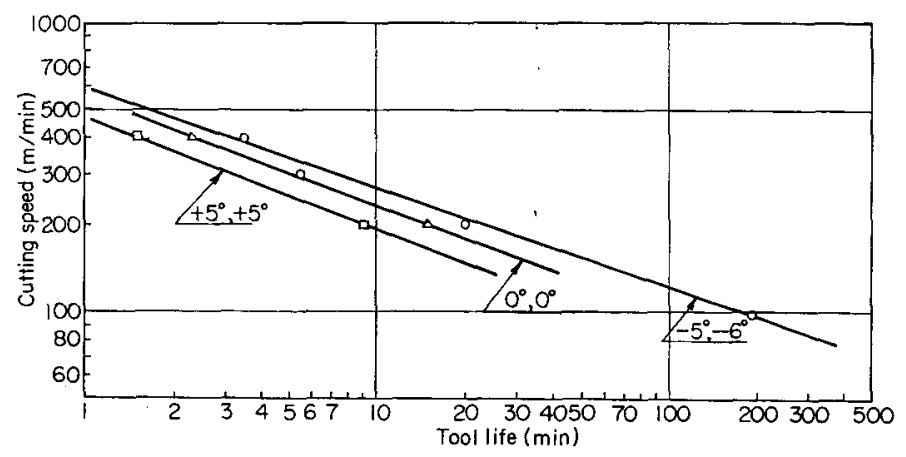

Fig. 2. Effects of rake angle on cutting performance of ceramic tool. Tool material; $\mathrm{Al}_{2} \mathrm{O}_{3}$ ceramic containing TiC carbide.

Feed : $0.1 \mathrm{~mm} / \mathrm{rev}$. Depth of cut : $0.3 \mathrm{~mm}$. Flank wear at tool life : $0.4 \mathrm{~mm}$ Two angles in each curve are front and side rake angles respectively. 


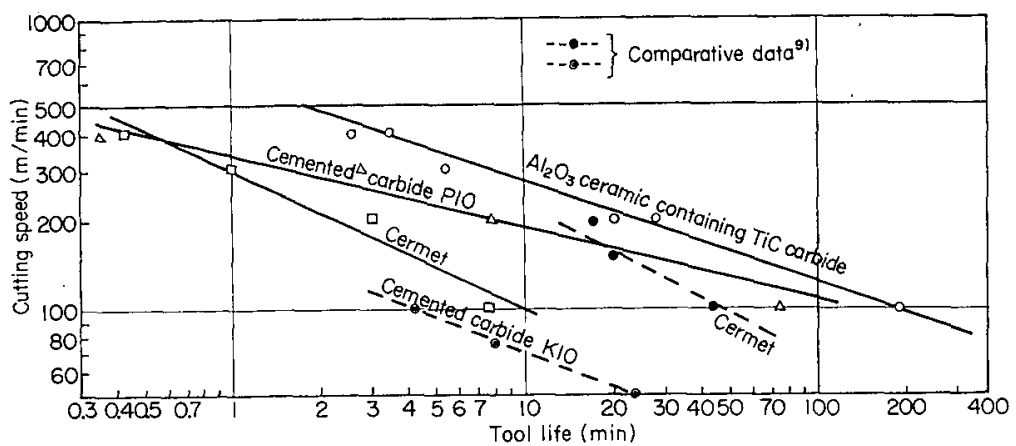

Fig. 3. Relationship between cutting speed and tool life for three types of tool in continuous cutting.

Feed : $0.1 \mathrm{~mm} / \mathrm{rev}$. Depth of cut : $0.3 \mathrm{~mm}$. Flank wear at tool life : $0.4 \mathrm{~mm}$.

発生するととなく，高い耐摩耗性を有し，高速では，他 の工具材質にはみられない長時間の丼命が得られる。低 速域での文定な切削性能は主として添加されている TiC の効果的な作炜にもとづくあのであり，眏速切削が可能 なのは， $\mathrm{Al}_{2} \mathrm{O}_{3}$ の役割に負うところが大である11)。安定 していて，しかも㳎範囲の速度領域での切削が可能であ るとすれば，鉄系焼結材料の上うに大量生産されるすの の自動盤に上る加工に，もっ之も適しているといえる.

\section{III -2 断続切削の工具寿命}

典型的な断続切削として正面フライス削りを行なった。 このフライス削りの埸合は，連続切削の場合とは買なり， カッ夕の回転時間と正味切削洔間上はかなり相違すると とになる. カッタ 1 回転中の正味切削時間はカッ夕径と 被削材幅扰よび切削速度によって異なる。寒用的には， カッ夕回転時間在工具寿命時闆として採用する方が便利 であるが，それでは連続切削上断続切削における切削性 能を正確に比較することができない，そこで，断続切削 でむ正味切削時間をとった，連続切削では，むちろん工 具驾常に切削に関与して拈り，その時間が正味切削時間 となる。
非常に興味深いことは，断続切削を行なったことによ り，工具摩耗上か損甥が特に著しい，ということがみら れないことである. Fig. 4 は，断繶切削における各工具 の毒命を示している．連続切削のデータは Fig. 3 から 再プロットしたものである.断続切削では, 被削材の量 が不足したという理由で $100 \mathrm{~m} / \mathrm{min}$ 附近での江具寿命 を求めなかったが，図でみるかぎり，カーバイド系せラ ミック之超硬の工具奉命は断続切削之連続切削では活之 んど差が認められない。サーメットはむしろ断続切削の 方が長い工具寿命となるが，乙れもさしたる差はないと みる心゙きであるう．とのように，両切削方式使命の差 がみら机ないというととは，いずれの工县材料ともに， 耐機械的衝撃抵抗䎲すぐれていることを物語るすのであ る.そして，断稳切削を連続切削と同一視してよいとと がわかる.したがって，てのような場合に，断続切削に 特有の配慮というあのは，とり立てて必瑟がないようで ある，考慮するとすれば，前節に述べたように，くり返 し衝撃に上る疲机強度の低下を防止するために，切对稜 に設けるランド幅を連続切削の場合よりも10〜20\%ぐら い広くとるこよであるう。

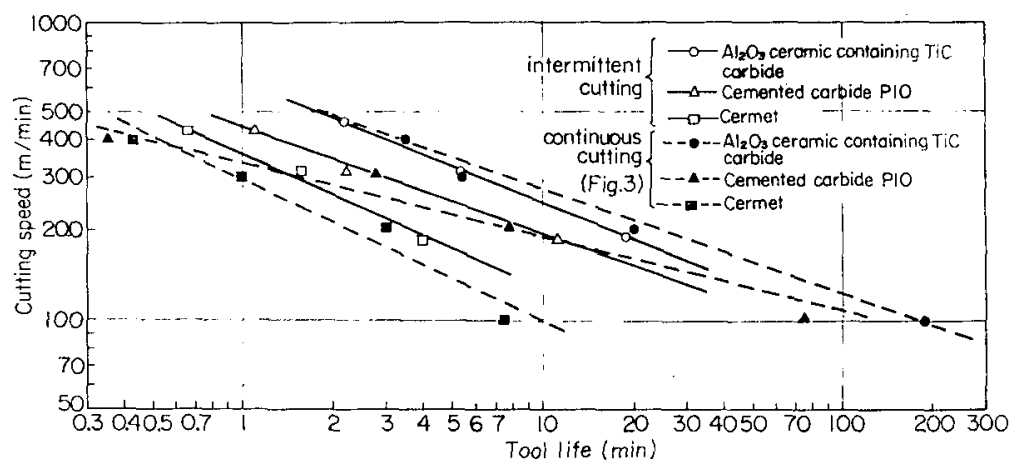

Fig. 4. Relationship between cutting speed and tool life for three types of tool in intermittent cutting (face-milling).

Feed : $0.1 \mathrm{~mm} /$ tooth.

Number of cutter blade : single blade.

Flank wear at tool life: $0.4 \mathrm{~mm}$.
Depth of cut : $0.3 \mathrm{~mm}$.

Cutting width : $\quad 50 \sim 82 \mathrm{~mm}$. 
cemented carbide P 10
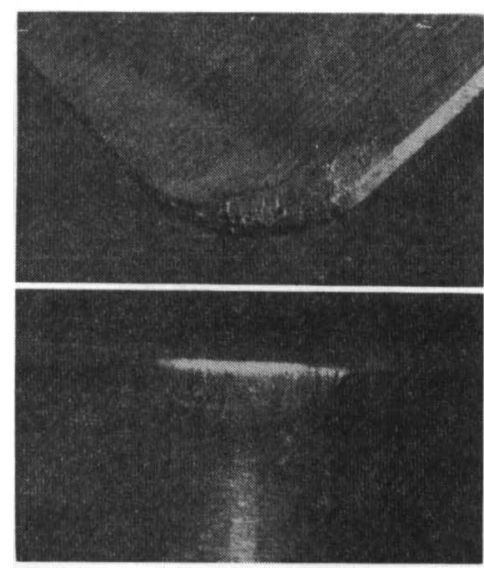

$\mathrm{V}=100 \mathrm{~m} / \mathrm{min}$

$\mathrm{T}=30 \mathrm{~min}$
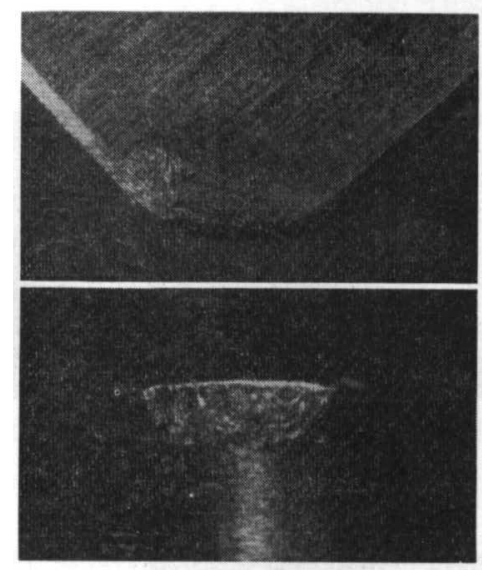

$\mathrm{V}=100 \mathrm{~m} / \mathrm{min}$

$\mathrm{T}=5 \mathrm{~min}$
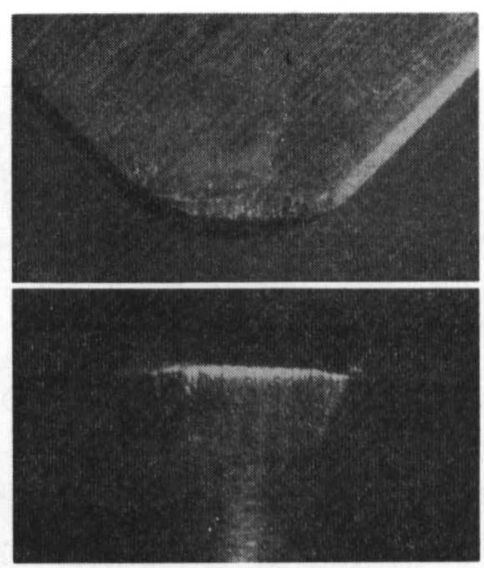

$\mathrm{V}=300 \mathrm{~m} / \mathrm{min}$

$\mathrm{T}=3 \mathrm{~min}$

\section{cermet}
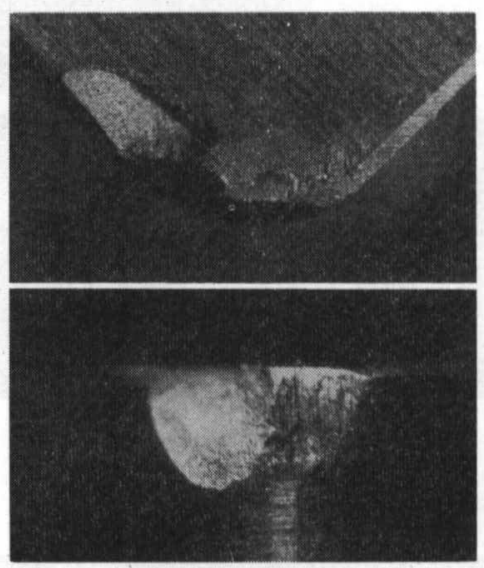

$\mathrm{V}=300 \mathrm{~m} / \mathrm{min}$

$\mathrm{T}=1.5 \mathrm{~min}$

$\mathrm{Al}_{2} \mathrm{O}_{3}$ ceramic containing $\mathrm{TiC}$ carbide

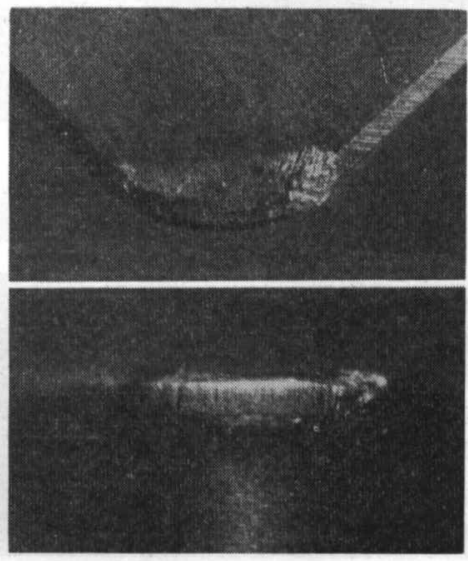

$\mathrm{V}=100 \mathrm{~m} / \mathrm{min}$

$\mathrm{T}=70 \mathrm{~min}$
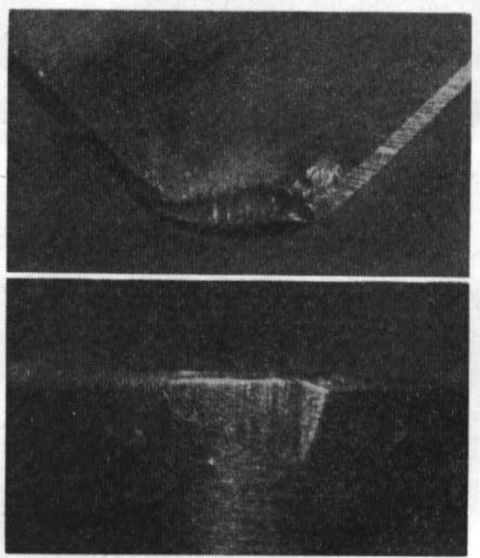

$\mathrm{V}=300 \mathrm{~m} / \mathrm{min}$ $\mathrm{T}=5.5 \mathrm{~min}$

Photo. 1. Wear marks and damages observed on three types of cutting tool in continuous cutting. V: Cutting speed

$\mathrm{T}$ : Machining time 
とくに注目すべきは，カーバイド采セラミックである. 従来のセラミックが, 鋳鉄の断続切削のみ可能であっ た13,14)ことからすると，鋼材の断続切削が可能になった ことは著しい進歩であるといわ柿ばならい. その上, これまで鉄系焼結材料の切削にセラミックが不向きであ る8) とされていたことが，逆にカーバイド系セラミック によって，あっと屯適している工具材質になったととに も注目すべきであろう。

\section{III - 3 工具損傷}

次に，連続切削および断続切削における工具の摩耗状 態を含めた損傷について触れておきたい.

Photo. 1 は, 連続切削における 3 種類の工具の摩耗と 損傷を切削速度上切削時間の関係で示している. 超硬 P 10 とカーバイド系セラミックの摩耗痕から，この両 者は, 比較的安定した切削を行なったととをうかがうこ とができる. こ机に対して，サーメットにおいては，逃 げ面摩耗痕からわかるように, 凝着物の離脱による上思
われるような，おう突のはげしい摩耗痕を呈する。ただ, この原因が熱的なものであるか機械的なあのであるかを 明言することはできない，屯し熱的な原因とすれば，す くい面も逃げ面と同様にはげしく摩耗されねばならない. ただ，ここで一般的に切くずの生成状態とその形状をみ て，それが連続流れ形を呈しながらあ比較的細かく切断 されて排出されることからみて，すくい面には，さほ上゙ の大きな機械的応力はかからなかったであろうと考えら れる. すなわち, 主分力が低めに測定される場合に相当 すると考えられる. したがって, 工具材料固有の高温で の熱的な材料学的特性（たとえば相手材との溶着性とか 耐酸化性など）上機械的な材料学的な特性（たとえば破 壊とか変形）の両者からきまってくるものであるとみら れる.

通常, アルミナ単味のセラミック工具は, 鋼材に対す る場合に切削速度が $100 \mathrm{~m} / \mathrm{min}$ あたりになる上低速性 の欠損を生じやすいととがよく知られている. ところが

cemented carbide P 10

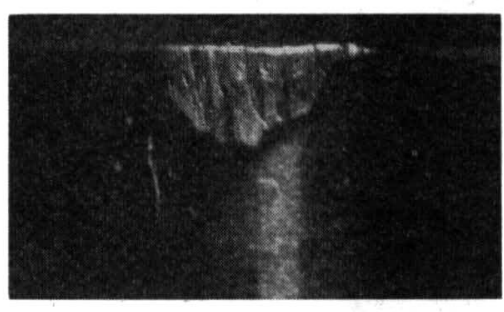

$\mathrm{V}=185 \mathrm{~m} / \mathrm{min}$

$\mathrm{T}=80 \mathrm{~min}$

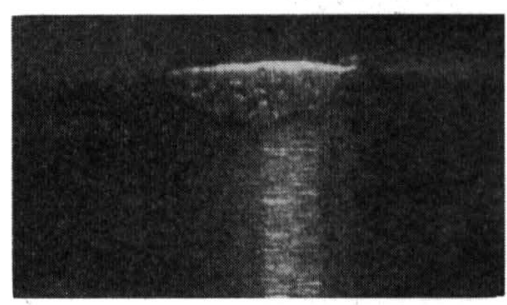

$\mathrm{V}=185 \mathrm{~m} / \mathrm{min}$

$\mathrm{T}=20 \mathrm{~min}$

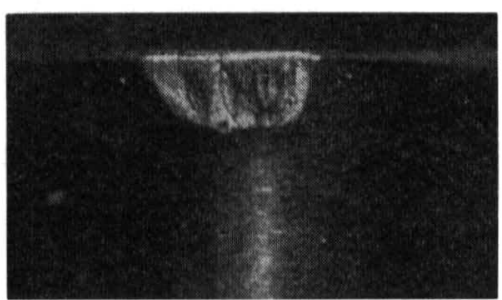

$\mathrm{V}=430 \mathrm{~m} / \mathrm{min}$

$\mathrm{T}=4 \mathrm{~min}$

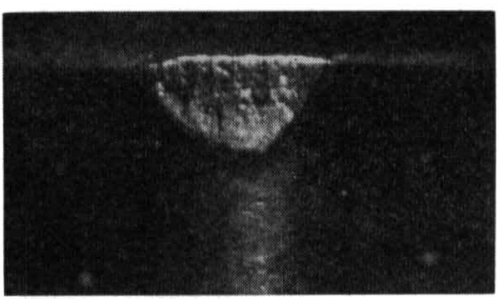

$\mathrm{V}=430 \mathrm{~m} / \mathrm{min}$

$\mathrm{T}=4 \mathrm{~min}$

$\mathrm{Al}_{2} \mathrm{O}_{3}$ ceramic containing $\mathrm{TiC}$ carbide

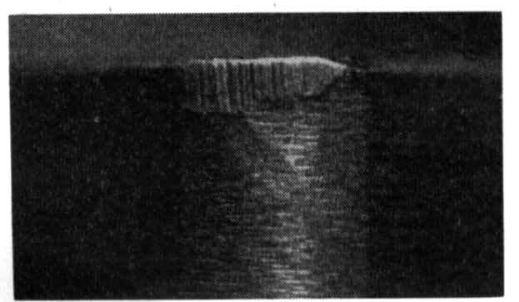

$\mathrm{V}=185 \mathrm{~m} / \mathrm{min}$ $\mathrm{T}=80 \mathrm{~min}$

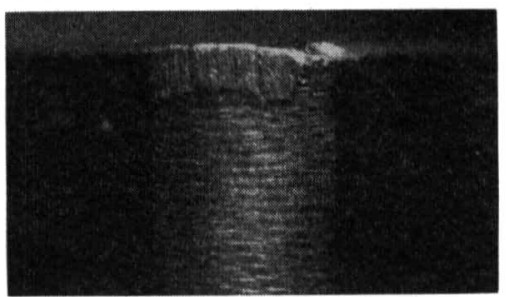

$\mathrm{V}=430 \mathrm{~m} / \mathrm{min}$

$\mathrm{T}=10 \mathrm{~min}$

Photo. 2. Flank wear marks observed on three types of cutting tool in intermittent cutting.

V : Cutting speed $\quad T$ : Rotation time of cutter 
カーバイド系セラミックは $100 \mathrm{~m} / \mathrm{min}$ においても非常 に安定した切削が可能であったし，巨視的にも微視的に む欠損を生じなかった。とれは，前節にす述べたように 添加された TiC の効果が低速で発揮されたとみるとと ができる.とのような $\mathrm{TiC} の$ 効果は，摩耗試験におい て明確にみられた11).

Photo. 2 は Photo.1 上同様に断続切削における逃げ 面の工具摩耗を示す. $400 \mathrm{~m} / \mathrm{min}$ をてえるような高速切 削においては，その高い切削温度に耐えられず超硬とサ 一メットは切为部で乾化変形（だれ）を生じ，同特には げしい機械的摩耗を生じるようになる。力ーバイド系セ ラミックの摩耗痕からは，高温で極端に強度低下したこ とによるとみられるような状況は観察されない，しかし， 通常の摩耗試験の結果加らすると，400〜 $500 \mathrm{~m} / \mathrm{min}$ 以 上ではむはや TiC 添加の効果がみられなくなり，これ に代って $\mathrm{Al}_{2} \mathrm{O}_{3}$ が酎摩耗性を発揮するようになる11). 超硬とサーメットは $185 \mathrm{~m} / \mathrm{min}$ の切削速度に打いても， すでに耐熱性にとぼしい状況になっていると推察される のである.

\section{$\mathrm{IV}$ 結 言}

以上の結果を総括すると，次のようになる.

1）工具すくい角は，負にとるのがよく，しかむ切刃 稜をナャンファしてランドを設けるのがよい。そのラン ド幅は，送り量をとえない程度で，2段すくい角になる ようにすべきである。

2）連続切削において，カーバイド系セラミックが工
具寿命および工具損傷のいずれの点でももっとも良好な 結果を示した。そ実用的な切削速度は $100 \sim 200 \mathrm{~m} / \mathrm{min}$ である。

3）正面フライス削りにおける断続切削でも，カーバ イド采セラミックの工具寿命がもっとも長い. そして， カーバイド系セラミックと超硬の寿命時間は連続切削に おけるそれにほば等しく，断続切削が工具摩耗にとくに 恶い影響を李たらさなかったことがわかったままた，奏 用的な切削速度は $150 \mathrm{~m} / \mathrm{min}$ 以下にあるといえる.

終わりに実験用被削材について種々御配虑いただいた 懒豊田中央研究所木村尚氏に厚く御礼申し上げる次第で ある。

\section{文献}

1）林：名古屋工業試験所報告， 5，(1965） 11 .

2) Roy, S. Famison, \& E. Geijer : Fifth Annual Meeting General Session on Powder Metallurgy April, 1959.

3) Höganas Sponge Iron Corporation

4) R. Huseby : American Machinist, 112, (1968) 43.

5）田中，津和，大森：精密機械，31，(1965） 100.

6）田中, 大森：昭和 43 年度精機学会秋大会前刷 p. 103

7）田中, 津和, 大森: 精密機械, 32, (1966) 703.

8) 大森：学位論文, 大阪大学, 昭和 45 年.

9）川崎製鉄：粉末冶金用鉄粉 KIP 技術資料 (3) p. 90 .

10) 杉田：マシニスト，17, (1973) 3 .

11）杉田：粉体扣よび粉末治金, 21 (1975) 213 .

12）杉田：姫路工業大学研究報告 No.19A (1966) 87.

13）杉田：学位論文, 大阪大学, 昭和40年.

14) T. Sugita : Reports of Himeji Institute of Technology No. 16A (1963) 71 . 